\title{
Colorectal Cancer cM1 TNM Finding v8
}

National Cancer Institute

\section{Source}

National Cancer Institute. Colorectal Cancer cM1 TNM Finding v8. NCI Thesaurus. Code C134137.

Colorectal cancer with metastasis to one or more distant sites or organs or peritoneal metastasis is identified. (from AJCC 8th Ed.) 